\title{
Enhancing Capacities in Nonviolent Communication to Change Perceptions and Addressing Root, Proximate and Tertiary Causes of Ethiopia's Tigray Crisis
}

\author{
Rehema Zaid Obuyi ${ }^{1,2}$ \\ ${ }^{1}$ U.S. Institute of Peace's Generation Change Fellows (GCFP), Youth Advisory Council (YAC) \\ ${ }^{2}$ Integrated Initiatives for Community Empowerment (IICEP), Nairobi, Kenya
}

Corresponding author: rehema.zaid@iicep.or.ke

Received: 19 Sept., 2020

Revised: 25 Nov., 2020

Accepted: 14 Dec., 2020

\begin{abstract}
The postponement of the Ethiopia's August 2020 elections (owing to the COVID surge) has been said to be the beginning of the Ethiopia November 4 Violence between Tigrayan groups and the national defense forces. Other reasons cited include the mutation of the conflict from a struggle for territorial expansion into a class struggle. Ethnic federalism and a reaction of the massive oppression and exploitation of the people of Ethiopia are also cited as probable reasons for the conflict. The contribution of leading scholars in influencing the existing literature highlighting the conflict has not been without a decry that they have overtime dominated the field, oblivious of the need to promote the participation of young minds in such contribution. The U.S. Institute of Peace Generation Change Fellows-Youth Advisory Council provides a platform through which youth provide thought leadership and amplify their voices in peacebuilding. The author, a member of the YAC, Kenya chapter, provides a detailed overview of the genesis and state of the Ethiopia conflict but moves ahead to provide strategic guidance on how non-violent communication can be used to improve relations and achieve sustainable peace. This article is largely a desk review, convening thoughts from key C/PVE, International relations, and security experts from the horn of Africa and beyond. The thoughts have been corroborated, compared, and contrasted but most importantly analyzed into critical lessons and recommendations for a better situation for Ethiopia. Excerpts from the views of the experts denote variated factors leading to the Tigray conflict; the postponement of the August elections, the 'Federalism state',' a long struggle for perceived oppression among a section of aggrieved Ethiopians have been presented as causes for the conflict. The allying of Somalia to Ethiopia, the surge of refugees fleeing to Sudan but above all the hard stance by Ethiopia's leadership on the situation are feared for escalation of the conflict'. The author highlights the five Pillars of Gandhian Nonviolence, managing negative and disruptive emotions, mending a dysfunctional communication ecosystem as well as anger management as key to addressing the Tigray Conflict. Like in the case of Gachacha courts of Rwanda, she appreciates the Oromia- the traditional Ethiopian justice System, a rich customary practice which, together with the above, could help change the situation.
\end{abstract}

Keywords: Youth, Theory, Ethnic, Federalism, Stereotypes, COVID-19, Tigray, Gandhi

Meala acknowledges the volatile nature of conflict in the Horn of Africa, although she expresses concerns that leading scholars have dominated in influencing the existing literature highlighting causal factors of

\author{
How to cite this article: Obuyi, R.Z. (2020). Enhancing Capacities in \\ Nonviolent Communication to Change Perceptions and Addressing \\ Root, Proximate and Tertiary Causes of Ethiopia's Tigray Crisis. Int. J. \\ Peace, Edu. Dev., 8(02): 59-68. \\ Source of Support: None; Conflict of Interest: None \\ क क
}


conflict, perceptions, and shaping policies [24]. To support the implementation of UN resolution 2250, promote ownership and sustainability, it is crucial that young people are not always at the receiving end but given an opportunity to participate in key decision making; this will not be realized if shaping policies and perceptions of causal factors in peacebuilding and conflict is exclusively left in the hands of the elites in the society.

The U.S. Institute of Peace (USIP) Generation Change Fellows-Youth Advisory Council (YAC) provides a platform through which youth provide thought leadership to participate in decision making and amplify their voices in peace-building at local, regional, and international levels. At a meeting to update YAC on the situation in Ethiopia on December 10th Ms. Susan Stigant, the Director of Africa Programs at the USIP, outlined numerous hurdles in addressing the conflict, including hardening stand by the federal government, blocking of Independent investigation, blocked communication, uncertainty of the political transition among other challenges. She underscored the need to find a lasting solution to the plight in Ethiopia.

The author, a member of the YAC, Kenya chapter, felt obliged to contribute to the course. In this article, she provides strategic guidance on how peace practitioners and conflicting parties in Ethiopia can use non-violent communication to improve relations and achieve sustainable peace through an expansion of skills in empathy, openness, kindness, and forgiveness. Essentially, her article provides a standardized conflict resolution model which can be used elsewhere around the globe.

\section{Contextual Background of the Conflict in Ethiopia}

We cannot discuss interventions for the conflict without Ethiopia is analyzing the genesis of the conflict. A number of scholars have come up with divergent views on the drivers of the now protracted conflict: The struggle between regional and central forces was a major driver of conflict in Ethiopian politics during the imperial periods Bahru [4].

Axt et al. [3]. highlights the various causes of conflict ranging from socioeconomic, politicocultural, historical, and identity constructions. The interconnectedness of causal factors from multiple viewpoints demonstrates that there is no single explanation for the conflicts in the Horn of Africa. Singer classifies conflict into the root, proximate and tertiary causes [31]. Other Studies revealed that there are two main broad categories of conflict in Africa, intra-state and inter-state conflicts. Kriesberg and Burton mention the most contentious causes as resources and interests or values and ideology [7]. Stigant in her podcast, outlines causes of the recent spark of violence to be multi-faceted; the postponement of the August elections by Prime Minister Abiy (owing to COVID-19 surge) being key. Abiy's term was ending in October. However, this was not well received politically with TPLF, (Tigray People's Liberation Front) rallying against the idea by proceeding to hold elections in Tigray in September, purposing not to recognize Abiy after October [35, 36]. This led to the spark of the November 4 Violence between Tigrayan groups and the national defense forces located Tigray.

The author is of the opinion that these could be symptoms of prolonged grievances, which have shifted the curve upwards from latent phase to war/conflict escalation phase hence the need for concerted efforts in conflict transformation to restore peace and stability in Ethiopia.

Gebru reiterates that the rebellion by the peasants to the state was a result of oppression and not because it was dominantly controlled by Shoan Amhara [15] Young further adds that the main push factor for students targeting the ruling class was a rejection of human exploitation, irrespective of ruler's ethnic background [39]. Although the original objective for the formation of ethnic federalism was to mitigate inter-ethnic conflict, research has proven that the frequency and intensity of ethnic conflicts escalated post-1991. This calls for further scrutiny on the effectiveness of ethnic federalism as a strategy to address civil wars as rooted in ethnic conflict.

Some scholars further argue that ethnic conflict in Ethiopia cannot be entirely blamed on ethnicity but rather on the politicization of ethnic identity 
by self-seeking politicians. Putting into perspective the theories of ethnicity, Primordialism argues that ethnic identity is ascriptive, in that membership is assigned at birth and thus difficult to change Isajiw [19]. Tying this to situational theories, which emphasizes the important function served by ethnic identity and ethnic groups in mobilization. The logic of the approach stems from the rational choice theory. A framework for understanding and often formally modeling social and economic behavior. Based on this approach, ethnicity is something that may be relevant in some situations but not in others. Individuals may choose to be regarded as members of an ethnic group if they find it to their advantage [13].

Geertz describes ethnic ties as deep natural connections inherent to all human beings that promote deep natural connections of people with the same ethnic identity viewed as a homogeneous group and stir division with others from a heterogeneous group [16]. This hypothesis is in agreement with how ethnicity is used as a mobilization tool in the current federal system in Ethiopia.

Aalen is of the opinion that over time, this conflict mutated from a struggle for territorial expansion into a class struggle. On the contrary [1], Asnake attributes all post-1991 inter-ethnic, rooted in the adoption of ethnicized state administrative structures because of Ethnic federalism [2]. To refute this, several scholars teaching at the then Haile Selassie University (HSIU) asserted that the reaction to the massive oppression and exploitation of the people of Ethiopia symbolizes a class struggle Young [39].

More scholars offered complimentary thoughts, aligning multiple causal factors to the conflict other than ethnic ideology. One such thought is the violent nature of how the assimilation and adaptation processes were executed during the integration processes leading to misinformation, i.e., generalizing ethnic prejudices and stereotypes as a key causal factor of this conflict.

Some of the probable reasons leading to this misconception are attributed to how the postEthiopia 1991 evolved marred with ethnicization of all the state structures, distribution of resources, and power. Habtu further backs this statement by specifically demonstrating how ethnic pluralism was approved by the Ethiopian Government as an organizing principle, creating multiple ethnic-based territorial units [17]. If we connect our initial outline on the root causes of conflict in Ethiopia and the above ethnic theory, the author argues that ethnic conflict cannot be blamed entirely on ethnicity but rather on the politicization of ethnic identity by self-seeking politicians. Sharp political divisions could also give rise to prejudices in cultural contexts, stereotypes, perceptions, negative attitudes, assumptions, and moralistic judgments, which are conflict escalation variables.

The stereotype in war settings is not something that can be underrated. It should be understood in terms of the chronic effects it has on individuals' social identity. There is no justification whatsoever for innocent children, the old and sick, and anybody who is not participating in war to suffer just because they belong or do not belong to a certain ethnic group.

Putting into perspective the Stereotype Theory according to World Bank Report, Ethiopia is the second-most populous nation in Africa after Nigeria and the fastest growing economy in the region with more than 112 million people (2019), [37]. The theory seeks to analyze the dimension of the impact of the conflict and further explaining the "feeling" of belonging or not belonging, tying it to the roots of Social identity Theory within/outgroups. In particular, this could serve as a platform aspect to demonstrate how manipulative ethnic divisions are created by those in power to isolate/ separate and create further differences. As evident from the preceding cited works, the youth are not seeing the struggle as one in which is solely based on ethnicity and that there is actually a measure of in-group connection which could be supported and expanded. Hence the need to elaborate the impact of Chronic Stereotype Threat \& Social Identity in war contexts.

According to Steele and Steele et al. when an individual is profiled in terms of or confirming 
negative bias ascribed to a certain group, then such individuals are said to have been subjected to stereotype threat $[33,34]$. There is a heavy outcry on social media; the current war in Ethiopia has rapidly mutated into ethnic targeting civilians based on ethnic identity. While Prime Minister Abiy has repeatedly assured the international community that no civilians were targeted on Igray, countless stories of refugees in Sudan contradict this statement.

BBC Soy reveals that the Ethiopian Government is using starvation as a weapon against the people of Tigray. It has blocked aid for 40+ days [32].

"Protecting these children, many of whom are refugees and internally displaced... must be a priority," said the UN's children's agency UNICEF.

"2.3 million children in Ethiopia's northern Tigray region are cut off from humanitarian assistance as violence continues" The UN has warned.

Seven weeks after the conflict began in the Tigray region of Ethiopia, the continuing lack of overall humanitarian access, coupled with an ongoing communications blackout in many areas, raises increasing concerns about the situation of civilians, UN High Commissioner for Human Rights Michelle Bachelet warned [42]. Additional complaints emerge from humanitarian agencies that despite initial agreement to grant humanitarian missions, the Ethiopian government denied their access to Tigray.

According to Geoffrey S. Corn, the Law of Armed Conflict (LOAC)-regulation of the conduct of warfare is essential for integrating humanity into war, preserving fundamental human rights, and assisting in restoring peace. Jus ad Bellum serves to regulate the conduct of going to war, while Jus in Bello serves to regulate conduct within war [12]. Tigray conflict is a manifestation of the humanitarian and moral dilemma. This calls for the enactment of the Responsibility to Protect (R2P) and immediate enforcement of the International humanitarian law (IHL) while at the same time observing the universal Declaration of Human Rights (UDHR) 1948. IHL is purely humanitarian, seeking to limit the suffering caused during war. On the other hand, Charlottesville, VA, describes (IHRL) as "inherent dignity" and "inalienable rights" of individuals [9].
In simpler terms, IHL applies only during armed conflict, while (IHRL) applies all the time.

Viewing the conflict from another angle while putting the "Resource Curse Theory" into perspective, different studies have suggested that demographic and environmental pressures have featured prominently in the debate over the new security challenges in the aftermath of the Cold War. Putting into consideration the negative effect of population growth on dwindling resources and youth bulges. Homer-Dixon reinforces this theory:

"Population-induced resource scarcity has been considered to be a security threat primarily in developing countries with low capacity to prevent and adapt to scarcities [18]."

As per USAID, Ethiopia's youthful population is an incredible asset and untapped resource for positive growth. Of Ethiopia's population, estimated at 104 million, 41 percent is under the age of 15. More than 28 percent are aged 15 to 29 . Youth unemployment is estimated at nearly 27 percent. One reason for the high youth unemployment rate is low literacy (68 percent) levels. Ethiopia's secondary school gross enrolment rate is 39.8 percent-far too inadequate for a country with Ethiopia's natural resources, economic potential, and global ambition. Technical and vocational education and training reached 352,000 students in 2015, and female enrolment continues to be higher than male enrolment [38]. Like in any other Society, the youth provide essential building blocks for development and prosperity. The case of Ethiopia is indifferent.

Urdal, H. is of the opinion that countries with youth bulge exceeding $20 \%$ of the adult population have a potential for the occurrence of conflicts [41]. However, contemporary human developmentalists strongly recommend shifting the focus from viewing youth as perpetrators or victims of violence to positive contributors Larson [23]. It is on this premise the author emphasizes introducing or reinforcing ongoing efforts to bring out the best from the youth.

The author sums up taking into consideration the rejection of ethnicity ideology as an explicit 
polarization factor to the conflict in Ethiopia. Based on such findings, it is important not to look at the surface drivers of this conflict but do an in-depth conflict analysis that will look at all dimensions, cognitive/perceptual, emotional, and behavioral. The foregone is in congruence with Cordell et al. who is of the opinion that ethnicity should not be underrated as a causal factor [11]. It has the power to induce a mobilizational basis for collective action. Although "holding all other factors constant" ethnicity solely as a driver does not have the power to be an ultimate, irreducible source of violent conflict.

\section{Psychological Dimension of the Conflict}

It is vital to be cautious about the radically changing trends of warfare and violent conflict by not overlooking a psychological dimension. This has to do with how people cognitively and emotionally process information. Leading to nonphysical camouflage war tactics such as engaging in propaganda, resulting in misinformation, disinformation, and false narratives Freund, A.M. et al. [14]. In contemporary societies, propaganda can have a major effect on warfare because of advanced technology. The negative perceptions, which most of the time, are inciting, can lead to violent conflict or escalation of the existing war.

Citing a specific example, Bar-Tal, argues that parties involved in a conflict always create a conflict-supporting narrative that provides an explanation and justification for their involvement, e.g., providing explanation and justification of the suffering and hardship that inevitably arises from violent conflict-for example, by giving a justification of their actions, beliefs, and perceptions at the expense of the opponent [5]. If these narratives are not checked on time by providing alternative narratives, it can provide a fertile ground for massive human rights violations. Nisbet, M. C. further adds that an analysis of narratives is important because it facilitates understanding of the information landscape that contributed to the conflict [28].

\section{Nexus Between Conflict and State of Mental Health}

It is important to explore how the impact on mental health as a result of the COVID-19 pandemic could shape the trends of Peace and Security in the Horn of Africa. One of the concerns raised by Crisis Group is the intersection of the pandemic with wars or political conditions that could give rise to new crises or exacerbate existing ones [10]. Further studies add that the 'vulnerability' of the population is one of the determinant factors on how they respond to social, economic, and cultural adjustments brought about by the pandemic. The pandemic has placed enormous stress on societies and political systems posing a risk to social order. UNDP asserts that the consequences of the COVID-19 pandemic could be long-lasting, resulting to delayed electoral processes, accountability, governance, peace, and security at the Horn of Africa and the Sahel [42]. The adverse effects of COVID-19 have impacted the social, economic, and mental health of youth in the Horn of Africa [27]. Nicola, Alsafi, Sohrabi, et al., further highlight the socio implications of the coronavirus pandemic on the education sector; [27]. According to the authors' analysis, the impact of having teenagers/youth away from school for a long time can have adverse effects, including teen pregnancies, increased drug consumption, the possibility of online radicalization, and recruitment into militia gangs. Research has proven that long exposure to polarized or depraved online content can further result in changing dynamics in crime and violent conflict due to the emergency of juvenile gangs with new warfare tactics. This, coupled with unattended mental health issues among youth, can have undesired effects on the trends of conflicts.

The author attributes deep underlying factors such as mental health issues as one of the triggers to the spark of violence on November 4, thus the need for concerted effort to mitigate the impact of COVID-19 on mental health.

The Regional Brief echoes above findings by further demonstrating how the multiple social economic variables as a result of COVID-19 measures impact each other. Citing a few examples, a weakened 
socioeconomic condition can give rise to civil unrest, loss of livelihoods, and increased food insecurity. There have also been increasingly reported cases of domestic violence due to lockdowns, Increased political stability as a result of the breakdown of peace deals and reforms. Additionally, Extremist groups, especially Al-Shabaab, could use the pandemic to improve their standing and increase their recruitment in Somalia and across the region. The focus of COVID-19 restriction measures was to mitigate negative health and socioeconomic impacts. On the contrary, these measures have the potential of significantly impacting governance, peace, and security and reversing gains made in Africa. All these factors, in the long run, contribute to mental health issues [30].

\section{Ethiopia's Tigray Crisis from a Gender Lens}

The conflict has economic, social, and psychological effects across all humanities. It is important to appreciate that the magnitude of these effects may have a strong gender variation Byrne thus the reason for gender analysis of this crisis [6]. The role of women in the society is not only enormous but also very influential. Being the primary agents of socialization, women are nurturers of key virtues for their children, as their first teachers Ntahobari and Ndayiziga [29]. The author emphasizes on the need to meaningfully engage women towards a peaceful and stable Ethiopia. An all-inclusive approach to mitigating this conflict is highly recommended. Moreover, warfare tactics meant to intimidate women, such as rape, should be investigated, and legal action taken on the perpetrators.

\section{Horn of Africa Expert's Views on Regional Impact of Ethiopia's Tigray Conflict}

Yusuf, a journalist from VOA, interviewed several scholars from the Horn of Africa, noting that the Impact of the Tigray Conflict is already felt in Sudan, Eritrea, and Somalia. He further adds that the Ethiopian government forces had captured the town of Alamata, 120 kilometers from the Tigray region's capital Mekelle, after nearly two weeks of fighting. In his submission, Dr. Mustafa Ali believes that despite this progression, the federal government is facing a long conflict. He moves on to express the likelihood of the fight turning into guerilla warfare which will make it difficult for Ethiopia to control TPLF. Ali further raises concerns of the influx of refugees with more than 20,000 civilians fleeing to Sudan, exacerbating the humanitarian crisis. Over time this number could increase further as the war progresses.

According to Thomas Murphy, the sub-Saharan Africa intelligence analyst for the Risk Advisory Group, the conflict will have an additional strain on Ethiopia's homeland security. Additionally, Comfort Ero: Africa program director for the International Crisis Group points out that this situation does not favor Somalia as it approaches its elections. He is equally concerned of the impact this conflict will have on Sudan, considering its fragility and coming at a time when Somalia enters its Election. The fact that Sudan is playing refuge will make it more unstable [40].

Mutahi. BBC Nairobi news correspondent also interviewed a number of leading Horn of Africa scholars in Peace and Security, Dr. Abdi, Horn of Africa analyst, is of the opinion that the impact is huge considering factors such as the involvement of Sudanese and the strategic position of Ethiopia which might lead the conflict to escalate to other countries in the region or even beyond. Fear is looming that Abiy may be forced to pull out of Amisom, thereby granting Al-Shabaab an open ticket for a resurgence.

Dr. Hassan Khannenje, Director of Horn Institute, feels that Prime Minister Abiy ought to have brought back Tigray in line with the federal government to avoid a situation where others could follow its example [26].

Yusuf indicated Abiy's hardstand in resolving the stalemate. His statement that: "His forces do not need assistance and can handle the fighting" [40] is unfortunate, taking into consideration the negative impacts of the crisis not only in Ethiopia but its neighbors at the Horn of Africa. 
There has been an ongoing effort by multiple stakeholders to put an end to the crises to mention. In a tweet, on 23 December UN High Commissioner for Human Rights Michelle Bachelet urged on use of non-violent approaches to solving this conflict. Her tweet quotes

"To avoid continued conflict and loss of life, Ethiopia should address its longstanding ethnic divides through accountability, inclusive dialogue, reconciliation and respect for human rights."

\section{Non-violence Communication Model}

This section will outline the process of Nonviolent Communication adopted from Dr. Vedabhyas Kundu, Programme Officer, Gandhi Smriti \& Darshan Samiti, New Delhi, India. It is taken from the free online course on non-violent communication being run by Gandhi Smriti.

https://www.gandhismriti.gov.in/announcement/ orientation-course-nonviolent-communication-0

\section{Why Nonviolent Communication}

"The golden rule of conduct...is mutual toleration, seeing that we will never all think alike, and we shall always see truth in fragment and from different angles of vision.... Even amongst the most conscientious persons, there will be room enough for honest differences of opinion. The only possible rule of conduct in any civilized society is, therefore, mutual toleration."

\section{- Mahatma Gandhi}

Most of the conflicts across the world happen when the communication ecosystem becomes dysfunctional, and there is a deficit in respect, understanding, acceptance, and trust. During conflicts, there is every possibility of a breakdown in communication with the conflicting parties not willing to talk to each other. Also, in conflict situations, the narratives become negative. The communication frame with which the adversaries operate is negative; the challenge is to transform it to a positive one. The conflicting parties inherently tell negative stories. Also, the challenge is to draw the adversaries into a process of genuine heart-toheart dialogue.
As we are trying to develop a model of conflict resolution in Ethiopia using the strategies of non-violent communication, it would be pertinent to understand on exactly what nonviolent communication is. Thakkar Kundu provides an expansive explanation of non-violent communication:

"To me, non-violent communication literacy would mean how our communication efforts should be nonviolent; how our ability and capacity to communicate not only with ourselves but with our family and society be non-violent in all aspects and overall, how the entire process of communication whether between individuals, groups, communities and the world at large should be non-violent in nature. This would entail deep understanding of the art and science of nonviolence and its centrality in all our daily actions. It's not just verbal and nonverbal communication, non-violent communication literacy would also include whether our thoughts and ideas are non-violent or not. This would also mean how we can rid of our preconceived notions of individuals or groups with whom we want to communicate and stop evaluating them to suit our own ideas. More than often, we are attuned to think in terms of moralistic judgments which may be our own constructions. By developing deep understanding of the art and science of nonviolence and integrating it in our communication practices we could get over with biased and moralistic judgments; this in turn could contribute to emotional bridge building.

By being non-violent communication literate, an individual/group/community will be able to selfintrospect whether the message they want to share has elements of violence and whether such a message will hurt others. Non-violent communication literacy would automatically help in strengthening and deepening relationships. When we are able to emotionally build bridges with others, we will be able to empathize with their views [20]."

Also, to understand why the use of non-violent communication is important, it would be pertinent to look at its different elements. These include Kundu:

1. Non-violent Communication means a complete lack of violence in the way we communicate with others. 
2. We should learn to communicate with ourselves and self-introspect.

3. Use of appropriate and positive language.

4. Avoiding stereotypes in our communication efforts.

5. Avoid moralistic judgments.

6. Avoid evaluative language.

7. Role of mutual respect in communication.

8. The Power of Empathy.

9. Strong belief in the power of compassion.

10. Connecting with needs of others.

11. Importance of flexibility in our communication.

12. Practicing active listening skills.

13. Expressing gratitude [21].

The overarching goal of using non-violent communication is emotional bridge building, strengthening, and deepening of relationships. Also, all the elements of non-violent communication are interconnected and interwoven; used strategically, it can help in constructive a healthy communication ecosystem.

The foundational architecture of non-violent communication are the five pillars of the apostle of peace, Mahatma Gandhi's five pillars of nonviolence. Kundu, 2020 His five pillars of nonviolence include respect, understanding, acceptance, appreciation, and compassion [21].

\section{The Nonviolent Communication Model for Resolving the Ethiopian Crisis}

As discussed above, non-violent communication entails a communication ecosystem that facilitates constructive conflict transformation, a win-win solution, and meaningful engagement with the conflicting parties.

Mahatma Gandhi's five basic pillars of nonviolence could be an important adoption to addressing the situation in Ethiopia. Respect is one of such pillars, which essentially seeks to affirm the need for upholding human dignity and shying away from any tendencies that may jeopardize the same. Understanding, a good virtue that stems from the need to be considerate to each other's views but also accommodating one another is an important aspect worth practice in the Ethiopia Crisis's. Excerpts from the forgone discussion have alluded to the lack of acceptance and the absence of appreciation which are key ingredients to harmonious living and co-existence. Last but not least would be the virtue of compassion; the act of kindness and love for one another are building blocks for a lasting relationship. As a passionate player for peace and non-violent conflict resolution, the author has a huge sense of conviction that the pillars, as embedded in the 5 major virtues of humanity, can be an important breakthrough towards the turmoil in Ethiopia.

When daggers are drawn (like in the case of Ethiopia) communication barrier is not uncommon. Suffice it to say parties in conflict choose no words for each other! The pillars of non-violence would be better accompanied by interweaving the key elements of non-violent communication for the constructive transformation of the conflict.

1. It is essential that the conflicting parties be brought to a common platform, a safe space where the parties are able to practice toleration of each other's views.

2. Encouraging the use of appropriate words and language in the process of conflict resolution is the key. Words hold power that can be used to instigate or neutralize any given experience. They can be used as weapons- either offense or defense. Archbishop Desmond Tutu had rightly pointed out, "Language is very powerful. Language does not just describe quality. Language creates the reality it describes. We should try to take responsibility of our actions, words, and feelings and not blame others for these."

3. Judgemental communication is life-alienating. Parties in conflict situations when they aim to resolve the crisis should avoid using moralistic judgments.

4. As in many parts of the world, there seems to be an empathy deficit which is becoming a roadblock towards an amicable resolution of the dispute. It is essential that empathetic connections and engagement between the 
conflicting parties are encouraged. Also, it critical to look at the concerns of those who are victims in a compassionate manner.

5. It is also critically to sufficiently look at the critical needs of those in conflicting parties and map on what the issues and concern due to which they are involved in this conflict.

To realize the gains of using non-violent communication, the author suggests training different stakeholders in Ethiopia on non-violent communication. Be it government officials, mediators, youth, and other stakeholders, and it would be useful if a sustained training program can be evolved. It will help in long-term trust-building, encourage deep and empathetic connections.

\section{CONCLUSION}

As the author summarizes this submission, she wishes to draw our attention to a call to applying non-violent communication in our day-to-day lives adhering to Five Pillars of Gandhian Nonviolence, managing negative and disruptive emotions, mending a dysfunctional communication ecosystem as well as anger management. Tigray Crisis could have been exacerbated by, among others, these key causes. Conflict Resolution rooted in a practice of dialogue is a significant consideration worth mentioning here. Like it was in the case of Gachacha courts of Rwanda, the author likes to appreciate the rich customary practice of the Ethiopian community, which fosters communal justice system; she appreciates the fact that, like in their day-to-day interactions, lots of conflicts have been addressed through the Oromia- the traditional Ethiopian justice System. The author concludes that for any society to ensure cohesiveness and harmonious coexistence, there is a need to ensure a non-violent communication ecosystem in all its dimensions.

\section{REFERENCES}

Aalen, L. 2002. Ethnic Federalism in a Dominant Party State: The Ethiopian Experience 1991-2000. Chr. Michelsen Institute.

Asnake K. 2002. "Federalism: Some Trends of Ethnic Conflicts and their Management in Ethiopia". http://www.1.un1.hamburg.de/ice2003politics.html.
Axt, Heinz-Jurgen et al. 2006. Conflict: A Literature Review, Duisburg: Jean Monnet Group, 23 February.

Bahru, Z. 2002. A history of modern Ethiopia: 1855-1991. Addis Ababa, Addis Ababa University Press.

Bar-Tal, D. 1998. Societal beliefs in times of intractable conflict: The Israeli case. International Journal of Conflict Management, 9: 22-50.

Byrne, Bridget 1996. Gender, Conflict and Development. Volume I Overview BRIDGE Report No. 34. December 1995, revised July 1996. Brighton, Institute of Development Studies, University of Sussex.

Burton, John W. 1990. Conflict resolution and prevention, New York: St. Martin's Press.

Cordell K. and Stefan, W. 2009. Ethnic conflict. CausesConsequences Responses, Cambridge: Cambridge Polity Press.

Charlottesville, V.A. 2016. Law of Armed Conflict Deskbook. The United States Army Judge Advocate General's Legal Center and School.

Crisis Group. 2020. Special Briefing 4 / The Covid-19 Pandemic And Deadly Conflict. Last Accessed on 24 March 2020. New York/Brussels.

Cordell, K. and Wolff, S. 2010. Ethnic Conflict: Causes, Consequences, and Responses. Cambridge: Polity press.

Corn, Geoffrey S. 2012. The law of armed conflict: an operational approach. Wolters Kluwer Law \& Business. 2012. ISBN 9781454806905. OCLC 779607396.

Ethnic World: Science Politics and Reality. Proceedings of the Joint Canada-United States Conference on the Measurement of Ethnicity April 1-3 1992, US Government Printing Office, Washington, DC, 407-427.

Freund, A.M. et al. 2013. Misinformation, Disinformation, and Violent Conflict from Iraq and the "War on Terror" to Future Threats to Peace: American Psychologist, 68(7): 487-501

Gebru, T. 1977. Rural protest in Ethiopia, 1941-1970: A study of three rebellions. Ph.D. dissertation, Syracuse University.

Geertz, C. 1973. The Interpretation of Cultures New York: Basic Books.

Habtu, A. 2004. "Ethnic Pluralism as an Organizing Principle of the Ethiopian Federation." Dialectical Anthropology, 28: $91-123$.

Homer-Dixon and Thomas F. 1999. Environment, Scarcity, and Violence. Princeton, NJ and Oxford: Princeton University Press.

Isajiw, Wserolod W. 1993. 'Definitions and Dimensions of Ethnicity: A Theoretical Framework' Statistics Canada \& US Bureau of the Census. Challenges of Measuring and Kriesberg, Louis 1982. Social conflicts, $2^{\text {nd }}$ ed. Englewood Cliffs, NJ, Prentice-Hall. Lasswell, Harold 
D. 1936. Politics: Who gets what, when, how. New York, NY, McGraw Hill. Cited in Stedman 1991:374.

Kundu, V. 2018. Nurturing Emotional Bridge Building: A Dialogue with Nagaland's Gandhi; Peaceworks, 8(1).

Kundu, V. 2020. Integrating Nonviolent Communication in Pedagogies of Media Literacy Education; in The Handbook of Media Education Research; Edited by Divina Frau-Meigs, SirkkuKotilainen, Manisha PathakShelat, Michael Hoechsmann and Stuart R. Poyntz; Wiley; 2020.

Kundu, V. 2020. Orientation Course on Nonviolent Communication; Gandhi Smriti and Darshan Samiti, New Delhi. https://www.gandhismriti.govin/announcement/ orientation-course-nonviolent-communication-0

Larson, R.W. 2000. Toward a psychology of positive youth development. American Psychologist, 55(1): 170.

Meala, T. 2011. The Causes of Return to Conflict and the Geographical Dynamics in the Horn of Africa: The Eritrean- Ethiopian Boarder Conflict. MA Dissertation in Politics, SAOS, University of London.

Muhabie, M. 2015. Ethnic Federalism: A Means for Managing or a Triggering Factor for Ethnic Conflicts in Ethiopia. Social Sciences, 4(4): 94-105.

Mutahi, B. November 14, BBC Nairobi: https://www.bbc.com/ news/world-africa-54904496.

Nicola, M., Alsafi, Z. and Sohrabi, C. et al. The socio-economic implications of the coronavirus pandemic (COVID-19).

Nisbet, M.C. 2009. Communicating climate change: Why frames matter for public engagement. Environment, 51: $12-23$.

Ntahobari, J. and Basilissa N. 2003. The role of Burundian women in the peaceful settlement of conflicts. In: UNESCO 2003, pp. 11-26.

Regional, B. 2020. The Impact of the COVID-19 Outbreak on Governance, Peace and Security in the Horn of Africa.

Singer, D. and Joel. 1996. 'Armed Conflicts in the Former Colonial Regions: From Classification to Explanation', in Luc van de Goor, Kumar Rupesighe and Paul Sciarone (eds.), Between Development and Destruction: An Enquiry into the Causes of Conflict in Post-Colonial States, London: Macmillan.
Soy, A. 2020. Ethiopia's Tigray crisis: BBC reports from a refugee camp on the Sudan-Ethiopian border. https:// www.bbc.com/news/world-africa-55327559.

Steele, C.M. 1997. A threat in the air: How stereotypes shape intellectual identity and performance. American Psychologist, 52: 613-629.

Steele, C.M. and Spencer, S.J. and Aronson, J. 2002. Contending with group image: The psychology of stereotype and social identity threat. Advances in Experimental Social Psychology, 34: 379-440.

Stigant, S. (Director of Africa programs at the United States Institute of Peace). (2020, November 19). Ethiopia's Escalating Civil Conflict (Audio podcast).

https://www.usip.org/index.php/publications/2020/11/susanstigant-ethiopias-escalating-civil-conflict.

The World Bank in Ethiopia 2020. www.worldbank.org/en/ country/ethiopia/overview

USAID Fact Sheet, Developing Ethiopia's Youth, July 2017 [1]. https://www.usaid.gov/sites/default/files/ documents/1860/Ethiopia-Fact-Sheet_DevelopingYouth_Oct-2018.pdf

Young, J. 2006. Peasant revolution in Ethiopia. Cambridge, Cambridge University Press.

Yusuf, M. 2020. Impact of Ethiopia's Tigray Conflict Felt in Sudan, Eritrea, Somalia: VOA.

Urdal, H. 2006. A clash of generations? Youth bulges and political violence. International Studies Quarterly, 50(3): 607-630.

United Nations Human Rights Office of the High Commissioner. (22 December 2020). Provide unhindered access to whole of Tigray to protect civilians, Geneva. 